\title{
Moral outrage and social distancing: bad or badly informed citizens?
}

\author{
Wim De Neys ${ }^{{ }^{*}}$, Matthieu Raoelison ${ }^{1}$, Esther Boissin ${ }^{1}$, Aikaterini Voudouri ${ }^{2}$, Bence Bago ${ }^{3}$, \& Michal Bialek $^{4}$ \\ ${ }^{1}$ LaPsyDE, CNRS \& Université de Paris, France \\ ${ }^{2}$ Vrije Universiteit Amsterdam, Netherlands \\ ${ }^{3}$ Toulouse School of Economics, France \\ ${ }^{4}$ Institute of Psychology, University of Wroclaw, Poland
}

\begin{abstract}
In response to the Covid-19 pandemic citizens around the globe were urged to practice social distancing. Although many complied, not everyone did. These violations led to sharp moral outrage about the alleged immoral behavior. However, it is an open question whether violators fully realized the severity of the virus threat. We therefore surveyed $(n=1657)$ to what extent people condemned social distancing rules violations, to what extent they respected these rules, and how likely they felt that not respecting the rules would get them and others infected. Results indicated that people who respect social distancing less and find these violations more permissible also believe that the virus is less likely to infect them or others. This implies that violators do not necessarily care less about others; they simply see the virus as less threatening. Therefore, caution is needed when attributing social distancing violations to a lack of moral character.
\end{abstract}

\section{Introduction}

When the Covid-19 pandemic hit the world, governments across the globe resorted to social distancing measures (e.g., keeping minimal distance, bans on gathering, stay-at-home policies) to try to slow the spread of the virus. Although many citizens readily adopted these measures, not everyone did. News reports documented how some individuals still flocked to beaches and parks, hung out with friends or staged house parties (Cummins, 2020; Ryan, 2020). These social distancing violations were met with moral outrage and sharp condemnation in the press and on social media (Coffey, 2020; Helweg-Larsen, 2020; Olle, 2002; O'Sullivan \& Patino, 2020). Violators were labeled as selfish, irresponsible, bad citizens whose moral compass is broken (Boag, 2020; Davis, 2020; Head, 2020; Iqbal \& Townsend, 2020; Kingwell, 2020).

An implicit assumption underlying much of this so-called "Corona shaming" (Iqbal \& Townsend, 2020) is that violators realized the impact of their behavior and knowingly violated the rules. At first sight, this assumption might not seem unreasonable. By early April 2020-the time the current study was run-the pandemic was at its peak in most western countries. Widely publicized daily death rates in Italy, Spain, France, and the United States ran into the hundreds or thousands. People were being bombarded with explicit footage from overwhelmed Intensive Care Units, makeshift morgues in the streets, and soldiers that were called in to transport the death. As one journalist implied, arguing that the public was not informed about the dangers of

Corresponding author: Wim De Neys, LaPsyDE (UMR CNRS 8240), Sorbonne - Labo Binet, Université de Paris, 46 Rue SaintJacques, 75005 Paris, France. Email : wim.de-neys@parisdescartes.fr 
Covid-19 would be akin to claiming that citizens living in 2020 would not know that smoking is bad for their health (Ryan, 2020).

At the same time, there are reasons to suspect that not everyone might have fully realized the severity of the threat. At the very least one should acknowledge that the public received mixed messages about the pandemic. In the US, Fox News called the virus a hoax (Stone, 2020) and President Donald Trump repeatedly stressed that the new virus was less threatening than the seasonal flu (Brooks, 2020). In the UK, Prime Minister Boris Johnson initially stated it was fine to shake infected patient's hands (Duncan, 2020). In Belgium, the Secretary of Health publicly denounced renowned virologist Marc Wathelet as a "Drama Queen" when he insisted on taking more stringent measures (Van Horenbeek \& Van Garderen, 2020). And it was not just journalists or politicians who downplayed the virus threat. Up until mid-March 2020 eminent psychologists and behavioral scientists such as Gerd Gigerenzer, Paul Slovic, and Cass Sunstein warned in op-eds and columns that people were overreacting and largely overestimated the risk they faced (Richie, 2020). Indeed, even the World Health Organization's expert virologists and epidemiologists admitted their communication long underestimated the virus threat (Debusschere \& Van Garderen, 2020; Thuburn, 2020). This lends some credence to the view that some people might have felt less obliged to follow social distancing rules simply because they perceived the virus to be less dangerous. In other words, social distancing violators may not necessarily be bad citizens but rather badly informed citizens. As Mounk (2020) put it, their only sin might be honest ignorance.

The present study was designed to shed light on this issue. We surveyed to what extent people condemned social distancing rules violations, to what extent they respected the rules themselves, and how likely they felt that not respecting the rules would get them and others infected. Our key question was whether the extent to which people condemned social distancing violations and respected the rules was linked to their perceived virus infection likelihood. If the "badly informed citizen" view is correct, we expect that people's behavior and moral condemnation of violations will be positively associated with the estimated infection likelihood. It should be specifically those people who perceive the infection likelihood as being lower, who will be less inclined to condemn violations and respect the rules themselves. However, if the "bad citizen" view is correct, we expect that everyone's threat estimation will be at similar levels and will not be predictive of one's moral evaluation and reported behavior.

In addition to studying people's current evaluations (i.e., near the peak of the pandemic in western countries), we also wanted to explore how their evaluations evolved during the crisis. Therefore, after people had answered the questions about their current beliefs, we also asked them to indicate how they felt about these same issues at the start of the pandemic in their country. Our goal here was to get an indication of how people looked back on their own past opinions and behavior.

We recruited volunteer respondents by publicizing the study in different countries. To get a diverse sample, the survey was translated into 8 different languages (English, French, Italian, Spanish, Polish, Greek, Chinese, and Dutch).

\section{Method}

\section{Open data statement}

All data and material can be retrieved from our osf page (https://osf.io/h3egn/). Our hypothesis and study design were preregistered (https://osf.io/pf8ws).

\section{Participants}

The study was approved by the ethical committee of the Institute of Psychology, University of Wroclaw. We surveyed a convenience sample of respondents that were recruited by postings on social media, bulletin boards, and email lists. Participation was voluntary and anonymous. The survey was run between April 2 and 
April 10, 2020. A total of 1657 respondents completed the survey ${ }^{1}$. Of the participants who completed the demographics information, $67 \%$ percent was female. The median age bracket was $35-44$ years and the median education level was at the Bachelor Degree level. Respondents came from over 40 different countries with a clear dominance of three Western European countries (France $n=403$, Belgium $n=280$, Italy $n=134$ ). A full overview of the demographics information can be found in Supplementary Tables S1-S6.

\section{Material}

The survey started with a short introduction stating:

"In response to the Corona/Covid-19 virus pandemic, many governments across the world enforced social distancing rules (e.g., keeping minimal distance, bans on gathering, stay-at-home measures) to slow the spread of the virus.

Please answer the following questions:"

After the introduction people were questioned about their current judgments. The first question asked people to what extent they condemned violations of social distancing rules:

"1. To what extent do you feel that violating social distancing rules is morally condemnable (i.e., how "wrong" is such behavior)?"

Participants responded on a 5-point response scale ranging from "1 - Totally fine to violate social distancing rules" to " 5 - Totally unacceptable to violate social distancing rules". The next question asked people how likely it would be for them to get infected if they did not respect social distancing rules:

\section{"2. How likely do you think it is that you will get Corona if you don't respect social distancing rules"}

Participants responded on a 7-point scale ranging from "1 - Extremely unlikely" to "7 - Extremely likely". The third question asked about the likelihood that not respecting social distancing would result in infecting somebody else:

"3. How likely do you think it is that you will infect somebody else if you don't respect social distancing rules?"

Participants again responded on a 7-point scale ranging from " 1 - Extremely unlikely" to "7 - Extremely likely". The fourth question asked to what extent participants respected social distancing rules themselves:

"4. To what extent do you respect social distancing yourself?"

Participants responded on a 5-point scale ranging from "1 - I never respect social distancing rules" to "5 - I always respect social distancing rules".

Next, we asked participants to report on their past judgments on these same four questions. Given that the start of the outbreak is somewhat hard to define universally, we tried to give responders a common and clearly identifiable time-point that could serve as a general reference point. We took advantage of the fact that during the time the survey was run, practically all governments had legally enforced social distancing rules. We therefore opted to ask people to report on their feelings right before their government enforced social distancing with the following introduction:

${ }^{1}$ Answering was not enforced. Completion implies that participants were presented the full survey (i.e., respondents can have missing data). 
"For the next questions we ask you to go back in time to the day before your government enforced social distancing rules (i.e., the day before they became legally enforced). It was not illegal to refrain from respecting social distancing rules at that point. They were still just recommendations."

Try to remember how you felt and perceived things before social distancing was enforced and answer the following questions:"

After the introduction, participants were presented the same four questions and response scales. The only difference was that the question and options were put in the past tense and asked about social distancing recommendations (instead of rules). A complete reproduction of the survey can be found in the Supplementary Material.

After the eight main questions, a page with demographics questions was presented. Participants were asked to indicate the country they lived in, their gender, age-range bracket $(1:<18,2: 18-24,3: 25-34,4: 35-44,5$ : 45-54, 6: 55-64, 7: 65-75, 8: >75), and education level (1: Less than high school degree, 2: High school degree, 3 : Bachelor degree, 4: Master degree, 5: Post master degree). After the country question, we also asked whether the specific region they lived in already legally enforced social distancing measures. We included the question to filter for possible regional differences within specific countries. However, $97 \%$ of participants who answered the question responded affirmatively. Since the rare negative responses also came from countries that had entered a nation-wide lockdown, we refrained from filtering for this question.

\section{Procedure}

After giving their informed consent, participants were presented the eight main survey questions and demographics questions. Participants were not forced to answer any of the questions and could advance to the next question without responding if they wanted to. The eight main survey questions were presented one-by-one on the screen and participants could not go back to a previous question. The demographics questions were presented on one single screen and participants could freely scroll through them.

The survey was translated into 8 different languages (English, French, Italian, Spanish², Polish, Greek, Chinese, and Dutch). All translations started from the English survey and were translated by native speakers of the foreign language who were highly fluent in English.

The survey was run between April 2 and April 10, 2020. We decided to halt the data collection because after an initial surge the daily response rate was down to about a dozen after one week.

All variables were treated as ordinal variables. We used the reported numerical answer option codes to analyze the data.

\section{Results}

Descriptive ratings. Figure 1 gives an overview of the results. Current ratings are shown on the left ("Now"), people's ratings about how they felt closer to the start of the pandemic-before social distancing was enforced-are shown on the right ("Before"). As the figure indicates, people's current ratings are overall very high. The median moral condemnation rating is at 4/5 ("Very unacceptable to violate social distancing rules"). Median self-reported behavior (i.e., respecting social distancing rules) is at 5/5 ("I always respect social distancing rules"). Likewise, people feel that the likelihood of getting infected or infecting others when they do not respect social distancing is at 6/7 ("Quite likely"). Interestingly, as the right-hand bars show, although people's retrospective ratings of their past evaluations are still fairly high (i.e., at or above the mid-points of the scales), they are clearly lower than their current ratings. Indeed, for each of the measures, the median rating drops a full-scale point. A Wilcoxon signed-rank test indicated that the decrease was significant for each of the

${ }^{2}$ After the study launched we noted a typo in one probability statement option in the Spanish version. However, Spanish version results were completed consistent with the English version. 
ratings, all $\mathrm{p}<.001$, rank biserial correlations between $.63-.973$. Hence, as the pandemic evolved, people's perceived infection likelihood increased, they tended to respect social distancing rules more, and violations were perceived as less permissible. A detailed overview of the summary statistics can be found in Supplementary Table S7.

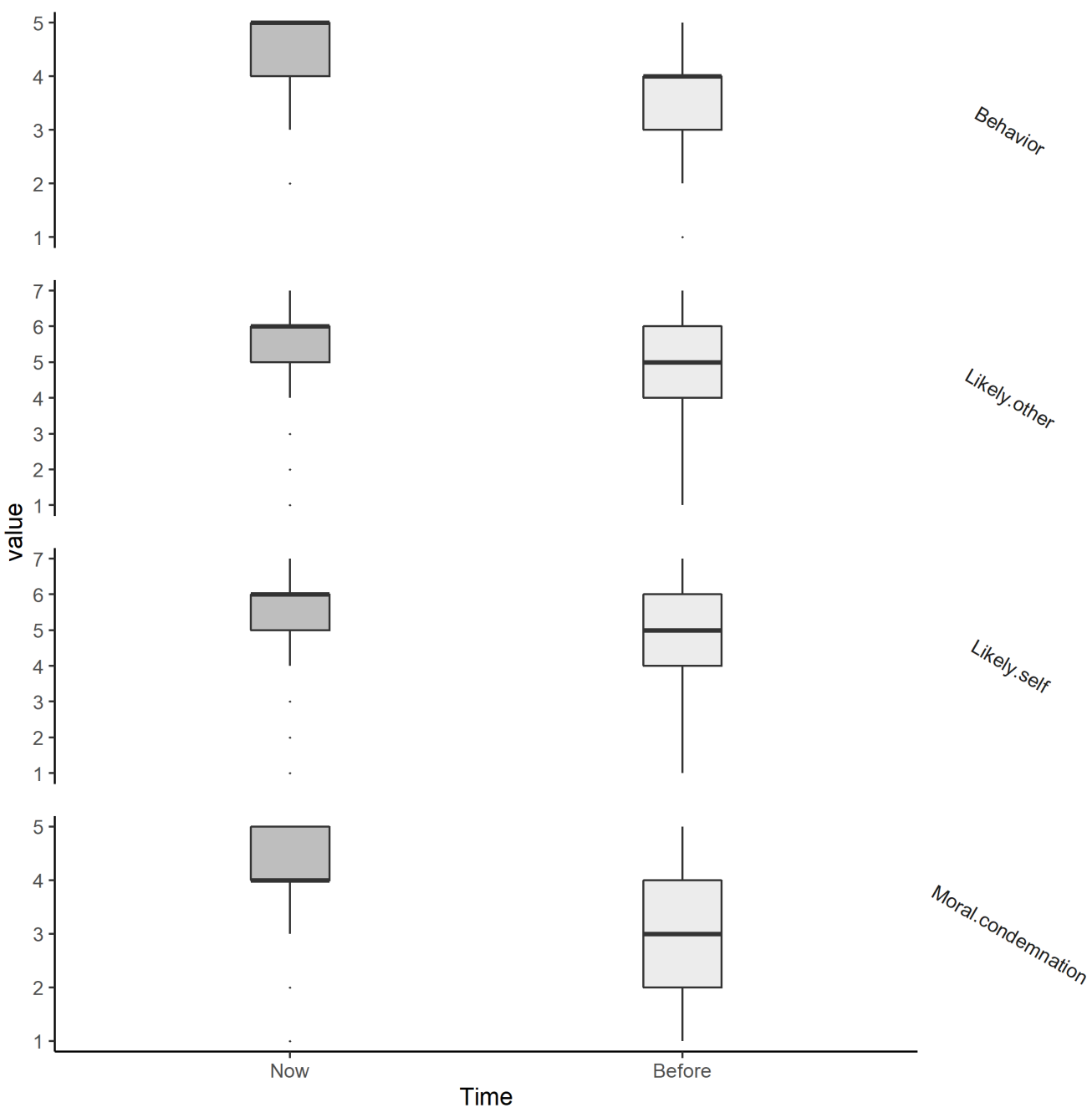

Figure 1. Descriptive ratings. Box plots showing respondents' current ("Now") and retrospective evaluations near the start of the Covid-19 pandemic ("Before"). Thick lines represent the median. Boxes denote the interquartile range.

Correlations. Our key question concerned the association between people's perceived infection likelihood and moral condemnation of social distancing violations and behavior. Table 1 shows the results. If we focus first on people's current evaluations, it is readily clear-perhaps unsurprisingly-that people's moral condemnation of social distancing violations and their (self-reported) behavior are correlated, $\mathrm{r}_{\mathrm{s}}=.39, \mathrm{p}<.001$. The more you respect social distancing yourself, the more you condemn violations. Likewise, people's perceived likelihood of getting infected themselves and infecting others is also highly associated, $\mathrm{r}_{\mathrm{s}}=.70, \mathrm{p}<.001$. Critically, the perceived infection likelihood (self and other) was indeed predictive of people's moral condemnation and own rule respecting behavior, $\mathrm{r}_{\mathrm{s}}=.23-.27$, all $\mathrm{p}<.001$.

Moving to people's evaluations of their own past experience-before social distancing rules were enforced - we find the same global pattern. Interestingly, it is noteworthy that correlations between people's past

3 The statistical tests are presented for completeness, we had no a priori hypotheses with respect to the effect. 
likelihood estimations and own distancing behavior, $\mathrm{r}_{\mathrm{s}}=.39-.34$, both $\mathrm{p}<.001$, and moral condemnation, $\mathrm{r}_{\mathrm{s}}=.46-$ .40 , both $\mathrm{p}<.001$, almost doubled in size compared to the current ratings. Hence, people who are less likely to perceive the virus as threatening, are also less likely to respect social distancing rules and condemn such violations and this was especially so during the early stages of the pandemic when social distancing was not legally enforced yet. Figure 2 illustrates these trends.
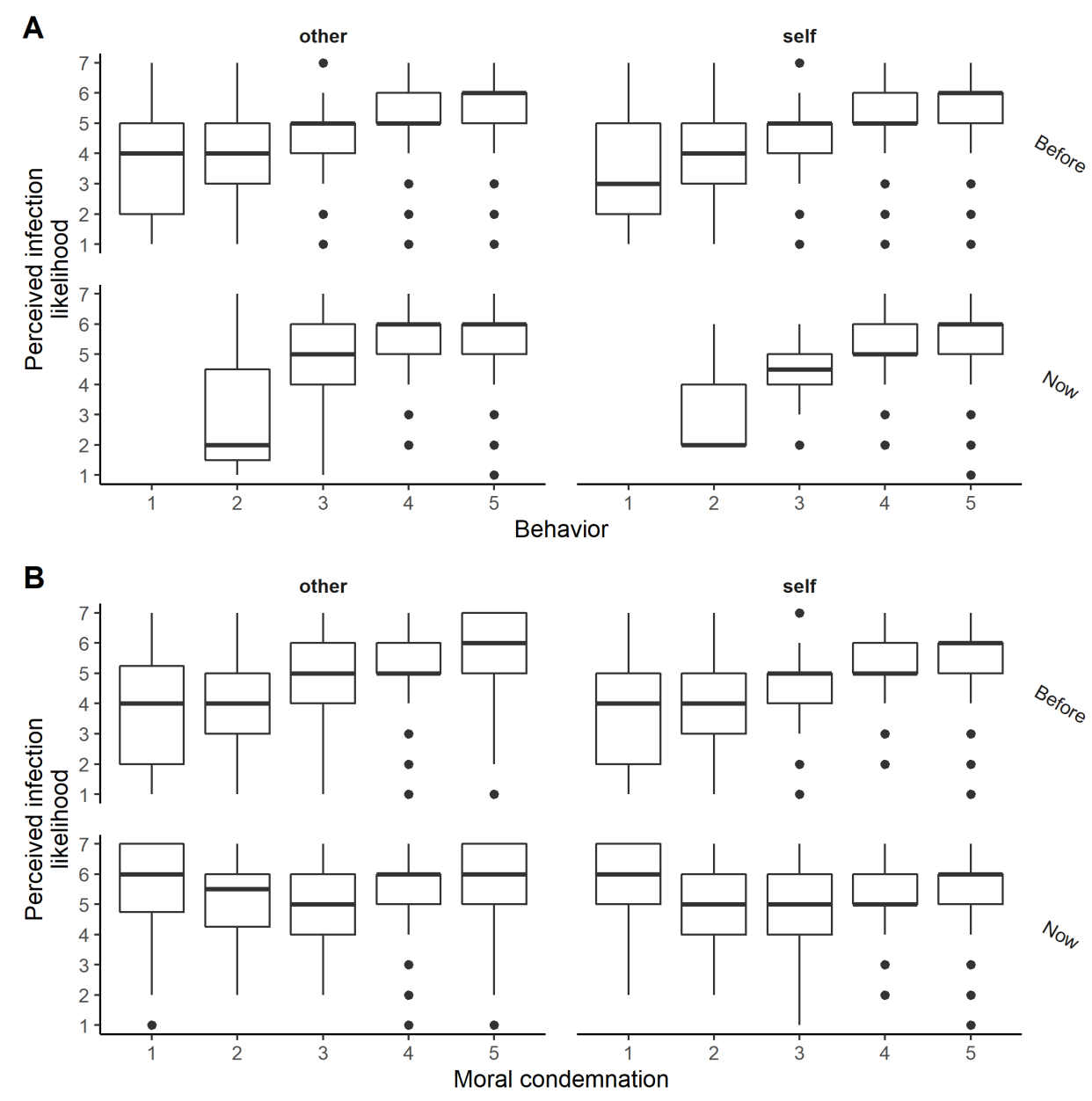

Figure 2. Boxplots illustrating the link between the perceived likelihood of Covid-19 infection (for others and self) and the extent to which participants report to respect social distancing (A. "Behavior") and condemn violations (B). The thick line represents the median. Boxes denote the interquartile range.

Table 1 also shows the associations between the various ratings and our demographic variables Age, Gender, and Education level. As the table indicates, age tended to be positively associated with all ratings except the likelihood to infect others. Hence, the higher one's age bracket, the higher one perceived the virus threat and the more one respected social distancing and condemned violations, both before and after social distancing was enforced. The gender variable was dummy coded as 0 (Female) and 1 (Male). There was a clear gender effect with females giving higher ratings on all our measures than males. Education level tended to be negatively associated with perceived virus threat. Hence, people with a higher education level tended to rate the likelihood of getting infected themselves or infecting others as slightly lower. Nevertheless, it should be stressed that the majority of our demographic variable associations were (very) small and should be interpreted with caution. 
Table 1

Overview of Spearman Correlations between the different variables

\begin{tabular}{|c|c|c|c|c|c|c|c|c|c|c|c|}
\hline & Moral condemnation & Likely self & Likely other & Behavior & Moral condemnation before & Likely self before & Likely other before & Behavior before & Age & Gender & Education \\
\hline Moral condemnation & - & & & & & & & & & & \\
\hline Likely self & $0.27^{* * * x}$ & - & & & & & & & & & \\
\hline Likely other & $0.24^{* x+x}$ & $0.70^{x \times x}$ & - & & & & & & & & \\
\hline Behavior & $0.39^{* x * t}$ & $0.24^{* * *}$ & $0.23^{* * x}$ & - & & & & & & & \\
\hline Moral condemnation before & $0.46^{* x *}$ & $0.19^{* * x}$ & $0.19^{* * x}$ & $0.27^{* x \star}$ & - & & & & & & \\
\hline Likely self before & $0.23^{* x *}$ & $0.50^{* \star x}$ & $0.43^{* x * x}$ & $0.25^{* * x}$ & $0.46^{* x *}$ & - & & & & & \\
\hline Likely other before & $0.19^{* * * x}$ & $0.40^{* * x}$ & $0.52^{* * 4}$ & $0.20^{* * \pi}$ & $0.40^{* 5 *}$ & $0.82^{25 *}$ & - & & & & \\
\hline Behavior before & $0.31^{1 * \pi *}$ & $0.20^{* * *}$ & $0.17^{* x+x}$ & $0.40^{* * \pi}$ & $0.56^{* \mathrm{x*}}$ & $0.43^{3 * x+x}$ & $0.39^{* * x}$ & - & & & \\
\hline Age & $0.21^{1 * x *}$ & $0.07^{* x}$ & 0.00 & $0.14^{* x *}$ & $0.17^{* \times * x}$ & $0.06^{*}$ & 0.02 & $0.16^{* x *}$ & - & & \\
\hline Gender & $-0.08^{* *}$ & $-0.14^{* x *}$ & $-0.13^{* x *}$ & $-0.12^{2 * x}$ & $-0.05^{*}$ & $-0.13^{* x * x}$ & $-0.11^{* x * x}$ & $-0.10^{* \times 8}$ & $0.10^{* x *}$ & - & \\
\hline Education & -0.02 & $-0.09^{* x \star}$ & $-0.10^{\mathrm{kxk}}$ & 0.04 & 0.02 & $-0.05^{*}$ & $-0.06^{x}$ & 0.01 & 0.04 & 0.02 & - \\
\hline
\end{tabular}
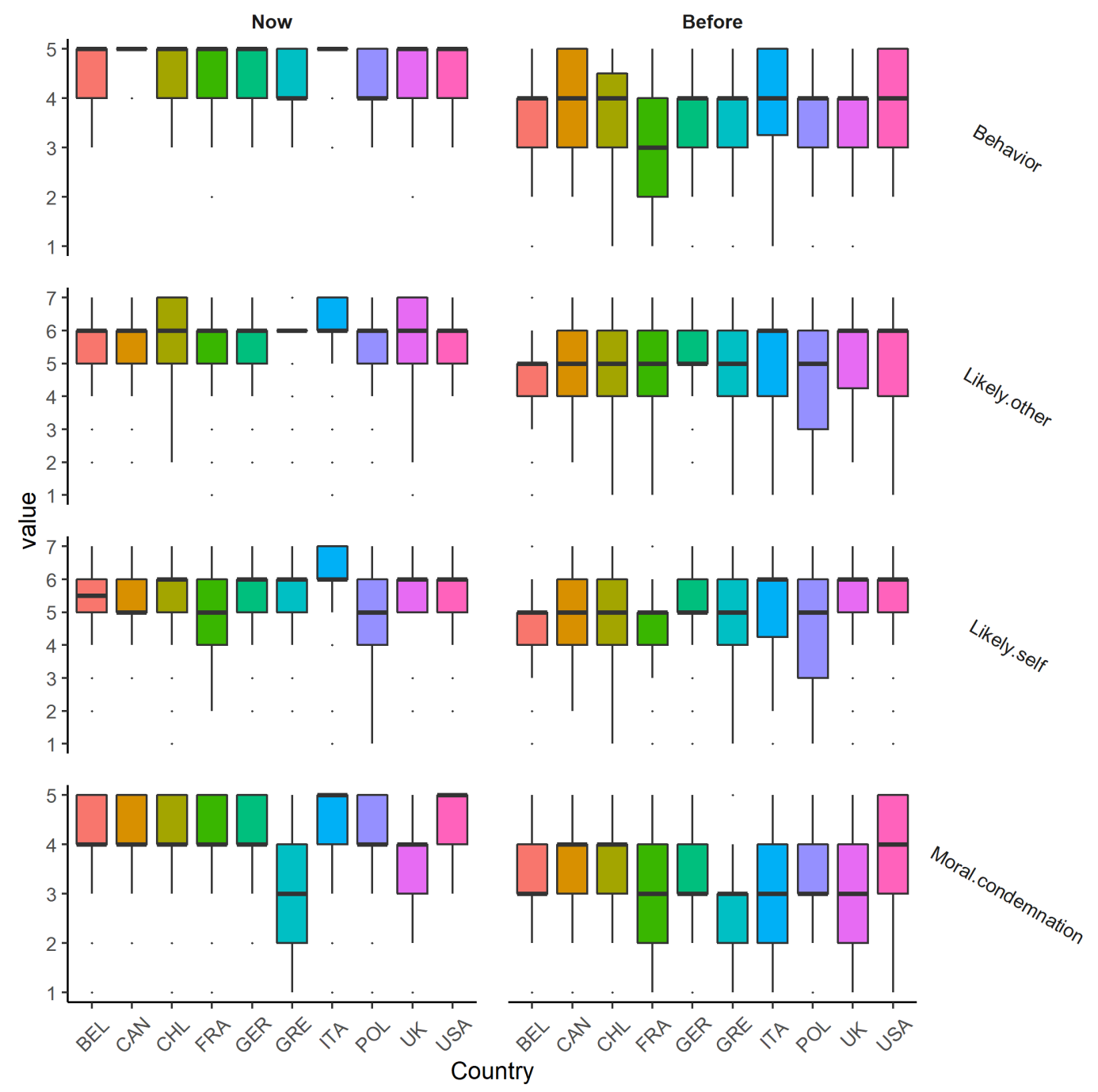

Figure 3. Descriptive ratings country level. Box plots showing respondents' current ("Now") and retrospective evaluation ("Before") for different countries. The thick line represents the median. Boxes denote the interquartile range. Note. $\mathrm{BEL}=$ Belgium, $\mathrm{CAN}=$ Canada, $\mathrm{CHL}=$ Chile, FRA $=$ France, GER $=$ Germany, GRE $=$ Greece, ITA $=$ Italy, POL $=$ Poland, UK $=$ United Kingdom, USA = United States of America. 
Country-level analysis. To get some general indication of the robustness of our findings we also explored the data at the individual country level. For the descriptive ratings overview, we restricted the analysis to respondents from the ten most frequently surveyed countries (i.e., France $n=403$, Belgium $n=280$, Italy $n=134$, Greece $n=94$, Chile $n=87$, Poland $n=62$, Germany $n=59$, UK $=43$, USA $=41$, and Canada $n=37$ ). Figure 3 shows the results. As the figure indicates, the overall pattern is observed in each of the individual countries, with current ratings near ceiling and lower retrospective ratings at the earlier time-point where social distancing was not yet enforced. As a side note, we mention that for each of our questions, the highest overall current ratings were recorded among Italian respondents. Perhaps not surprisingly, at the time when the survey was conducted, Italy was at the center of the pandemic with the highest number of Covid-19 cases and death rate in the world.

To avoid spurious conclusions, we restricted our country-level correlational analysis to the three countries for which we had the biggest sample sizes (+100 respondents, i.e., France, Belgium, and Italy). Results showed that the overall pattern was observed in each of these individual countries. Moral condemnation significantly correlated with perceived infection likelihood and this association was stronger earlier on in the pandemic. A full overview of these individual country level correlations can be found in Supplementary Tables S8-S10 and Figure S1.

Taken together, these findings suggest that our findings show some generalizability across different countries and are not driven by one or the other outlying nation.

\section{Discussion}

Our results clearly indicate that people's moral condemnation of social distancing violations and their own social distancing behavior are linked to their Covid-19 infection threat perception. Those who feel that the virus is less threatening are less likely to respect social distancing rules and to condemn such violations. This association was observed for people's current evaluations (i.e., at the peak of the pandemic in Europe) but was especially clear when they reported on the early stage of the pandemic when social distancing was not enforced yet. As the pandemic evolved, people's perceived infection likelihood, respecting of social distancing, and condemnation of violations all increased and reached near ceiling levels.

These findings lend some credence to the "badly informed citizens" position. People who respect social distancing less and find these violations more permissible are not necessarily bad citizens who do not care about others. They simply see this behavior as less threatening than others and therefore might see less need to respect the rules. This should give some pause for thought before we brand social distancing violators as "immoral" or "selfish". Instead of shaming people for their lack of moral character, it might be more productive to properly inform them about the threat of the virus.

This conclusion might be relevant when thinking about possible interventions. For example, one recent experimental study (Everett, Colombatto, Chituc, Brady, \& Crockett, 2020) found that manipulations that stressed people's moral obligation to adopt social distancing behavior (e.g., "It's your duty!", “Be a good person!") had little impact on participants' social distancing intentions and beliefs. Although speculative, in line with the current suggestions, it might prove to be more effective here to try to directly alter (i.e., boost) people's threat perception.

More generally, we feel that social distancing violations might have received too much attention and sketched too bleak a picture of the public's responsiveness to the Covid-19 pandemic. Indeed, the contrast between people's current and past evaluations in the present study illustrates how people updated their moral opinion and (self-reported) behavior in a matter of weeks. This swift behavioral change also seems to be backedup by location tracking data that points to a dramatic drop in people's movements since the start of the pandemic (Google Covid-19 Community Mobility Report,2020; Koksal, 2020). In the light of how hard it can be to change people's behavior and beliefs concerning numerous societal challenges (e.g., obesity, climate change, etc.) this is quite remarkable (e.g.,Thaler \& Sunstein, 2009). Many of these societal challenges have in common that people 
need to pay a current cost to avoid far bigger future negative consequences. However, whereas these future consequences are typically only observed years or decades later, in the Covid-19 case, people saw the catastrophe evolve under their eyes. For many, in a mere matter of weeks, the virus went from being perceived as a local problem in a far-away city they had never heard of, to a global threat that wrecked the world economy and wreaked havoc in the streets of Venice, Paris, and New York. We speculate that the short-time scale played an important role in people's updating of their threat and moral permissibility perceptions. Our study was not designed to address this issue, but the observed shift in respondents' evaluations does suggest that citizens' response to the crisis should not be underestimated.

To our knowledge, the present study is the first to examine the link between moral outrage concerning social distancing and Covid-19 threat perception. Clearly, it will be important to look for additional data and validation before drawing strong conclusions. Although we believe that our design choices were sensible, it is important to bear potential study limitations in mind. First, we used a crowdsourcing approach in which we recruited a multinational convenience sample of volunteer respondents. This allowed us to test a diverse, anonymous sample and get some indication of the specificity of the findings at the country level. However, the sample was not randomly selected or nationally representative concerning the underlying demographics. Second, the survey relied on self-reports and retrospective evaluations. Social desirability, reputation concerns, and memory biases might have affected the results. Finally, the study was correlational in nature and does not allow causal claims (e.g., did condemnation of social distancing violations increased because people's threat perception increased, or vice versa?).

One factor that might receive further attention is the precise role of intuitive and deliberate thought processes (De Neys, 2006; Evans, 2008; Kahneman, 2011) in people's infection threat and moral permissibility perception. It has long been established that people tend to make likelihood estimations based on intuitive rules of thumb rather than based on more effortful, deliberate thinking (Kahneman, 2011). For example, we tend to judge the likelihood of an event by the ease with which an example comes to mind. Consequently, more vivid and salient events will be perceived as more probable. We suspect that such intuitive processes played an important role in the high infection likelihood ratings we observed in the current study. Perhaps somewhat ironically given some psychologists' initial claims to the contrary (e.g., DeSteno, 2020; see Ritchie, 2020), people's tendency to rely on intuitive risk assessment processes might have been a blessing rather than a curse from a pandemic-control policy perspective. If this speculative suggestion is correct, it might also cast some grim prospects for the months following the peak of the pandemic and the efforts to prevent a new outbreak. At the point where daily death rates will start to decrease and Intensive Care Units start to empty, people's threat perception will likely also decrease and it might become especially challenging to get people to continue to practice social distancing. Put differently, from a societal point of view, the biggest challenge might not be to get citizens to respect social distancing rules at the point where their threat perception is peaking but to keep people to stick to this behavior when they start to perceive the virus as less threatening.

In general, we believe that psychologists, behavioral, and cognitive scientists have an important role to play in monitoring the public's Covid-19 perceptions and in designing possible interventions to get people to adopt the necessary public health behavior (e.g., Everett et al., 2020; Pennycook, McPhetres, Bago, \& Rand, 2020; Van Bavel et al., 2020). Although we should avoid jumping to policy recommendations (Chater, 2020; Richie, 2020), we believe such recommendations must be informed by insights into the psychological mechanisms underlying the public's response to the Covid-19 threat. We hope the present study can contribute to this challenge by showing that it might be wise to refrain from readily attributing violations of social distancing measures to a lack of moral character per se. 


\section{References}

Brooks, B. (2020, March 13). Like the flu? Trump's coronavirus messaging confuses public, pandemic researchers say. Reuters, Retrieved from https://www.reuters.com/article/us-health-coronavirus-mixed-messagesidUSKBN2102GY

Boag, K. (2020, March 23). Coronavirus puts a spotlight on the moral compass of America. CBC news, Retrieved from https://www.cbc.ca/news/world/keith-boag-coronavirus-moral-character-1.5505963

Chater, N. (2020). Facing up to the uncertainties of COVID-19. Nature Human Behavior. Online publication https://doi.org/10.1038/s41562-020-0865-2

Coffey, D. (2020,March 17). Parisian nonchalance shattered by Macron's coronavirus address to the people. RFI, Retrieved from https://amp.rfi.fr/en/europe/20200317-parisian-nonchalance-shattered-by-macron-scoronavirus-address-to-the-people

Cummins, E. (2020, March 24). "I'll do what I want": Why the people ignoring social distancing orders just won't listen. Vox, Retrieved from https://www.vox.com/the-highlight/2020/3/24/21191184/coronavirus-socialdistancing-pandemic-spring-break-keep-calm-carry-on

Davis, S. (2020, March 23). Coronavirus: People slammed as 'insensitive' and 'arrogant' for ignoring social distancing pleas. Euronews, Retrieved from https://www.euronews.com/2020/03/23/coronavirus-peopleslammed-as-insensitive-and-arrogant-for-ignoring-social-distancing-plea

Debusschere, B., \& Van Garderen, F. (2020, April 18). Belgische WHO-topman Hans Kluge: 'Iedereen heeft dit onderschat' [Belgian WHO-chairman Hans Kluge: 'Everybody underestimated this']. De Morgen, Retrieved from https://www.demorgen.be/nieuws/belgische-who-topman-hans-kluge-iedereen-heeft-ditonderschat $\sim \mathrm{b} 1 \mathrm{~b} 7 \mathrm{e} 1 \mathrm{ca} /$

DeSteno, D. (2020, Februaru 11). How fear distorts our thinking about the Coronavirus. The New York Times, Retrieved from https://www.nytimes.com/2020/02/11/opinion/international-world/coronavirus-fear.html

De Neys, W. (2006). Dual processing in reasoning: Two systems but one reasoner. Psychological Science, 17, 428433.

Evans, J. S. B. (2008). Dual-processing accounts of reasoning, judgment, and social cognition. Annual Review of Psychology, 59, 255-278.

Everett, J. A. C., Colombatto, C., Chituc, V., Brady, W. J., \& Crockett, M. (2020, March 20). The effectiveness of moral messages on public health behavioral intentions during the COVID-19 pandemic. https://doi.org/10.31234/osf.io/9yqs8

Duncan, C. (2020, March 27). Coronavirus: How Boris Johnson ignored health advice at his peril before Covid-19 diagnosis. The Independent, Retrieved from https://www.independent.co.uk/news/uk/politics/coronavirus-boris-johnson-positive-test-health-adviceshaking-hands-hospital-hancock-a9430231.html

Google Covid-19 Community Mobility Report. (2020). Retrieved from https://www.google.com/covid19/mobility/

Head, M. (2020, April 27). The COVID-19 crisis is being exacerbated by the selfishness and hyper-individualism of the British people. Varsity, Retrieved from https://www.varsity.co.uk/opinion/18983

Helweg-Larsen, M. (2020, March 27). Commentary: Partying and picnicking with friends? Your complacency this COVID-19 outbreak is misplaced. CNA International Edition, Retrieved from https://www.channelnewsasia.com/news/commentary/coronavirus-covid-19-safe-distancing-socialisolation-measure-us- 12577568

Iqbal, N., \& Townsend, M. (2020, April 18). Duty or score-settling? Rights and wrongs of corona-shaming. The Guardian, Retrieved from https://www.theguardian.com/society/2020/apr/18/duty-or-score-settlingrights-and-wrongs-of-corona-shaming

Kahneman, D. (2011). Thinking, Fast And Slow. Macmillan. 
Kingwell, M. (2020, March 12). Social distancing is not about panic. It's about being a good citizen. The Globe and Mail, Retrieved from https://www.theglobeandmail.com/opinion/article-social-distancing-during-covid-19its-not-panic-its-being-a-good/

Koksal, I. (2020, April 7). Google starts to publish Coronavirus mobility report. Forbes, Retrieved from https://www.forbes.com/sites/ilkerkoksal/2020/04/07/google-starts-to-publish-coronavirus-mobilityreports/\#496445c415a3

Mounk, Y. (2020, March 19). Four theories for why people are still out partying. Our moral instincts don't match this crisis. The Atlantic, Retrieved from https://www.theatlantic.com/ideas/archive/2020/03/moralinstincts-coronavirus/608305/

Olle, E. (2020, March 20). Packed Bondi Beach sparks outrage from many amid coronavirus crisis. 7 News, Retrieved from https://7news.com.au/lifestyle/health-wellbeing/packed-bondi-beach-sparks-outrage-frommany-amid-coronavirus-crisis-c-755181

O'Sullivan, F., \& Patino, M. (2020, March 16). Virus \#Irresponsables put France on lockdown. CityLab, Retrieved from https://www.citylab.com/life/2020/03/coronavirus-france-social-media-irresponsables-covid$\underline{19 / 608080 /}$

Pennycook, G., McPhetres, J., Bago, B., \& Rand, D. G. (2020, April 14). Predictors of attitudes and misperceptions about COVID-19 in Canada, the U.K., and the U.S.A. https://doi.org/10.31234/osf.io/zhjkp

Richie, S. (2010). Don't trust the psychologists on coronavirus. Unherd, Retrieved from https://unherd.com/2020/03/dont-trust-the-psychologists-on-coronavirus/

Ryan, F. (2020, March 24). Don't just blame the public over social distancing. Look to the government. The Guardian, Retrieved from_https://www.theguardian.com/commentisfree/2020/mar/24/social-distancinggovernment-covid-19

Stone, K. (2020, April 2). Washington State Group Is 1st to Sue Fox News for Calling Coronavirus a 'Hoax'. Times of San Diego, Retrieved from https://timesofsandiego.com/business/2020/04/02/washington-state-group-is1st-to-sue-fox-news-for-calling-coronavirus-a-hoax/

Thaler, R. H., \& Sunstein, C. R. (2009). Nudge: Improving Decisions About Health, Wealth, And Happiness. Penguin.

Thuburn, D. (2020, January 28). WHO Has Admitted an Error in Its Assessment of Wuhan Coronavirus Risk. ScienceAlert, Retrieved from https://www.sciencealert.com/who-tries-to-correct-wuhan-coronavirus-risk$\underline{\text { level }}$

Van Bavel, J. J., Baicker, K., Boggio, P., Capraro, V., Cichocka, A., Crockett, M., ... Willer, R. (2020, March 24). Using social and behavioural science to support COVID-19 pandemic response. https://doi.org/10.31234/osf.io/y38m9

Van Horenbeek, J., \& Van Garderen, F. (2020, April 4). Hoe ook ons land de pandemie onderschatte [How our country underestimated the pandemic]. De Morgen, Retrieved from https://www.demorgen.be/nieuws/italie-heeft-het-verkloot-voor-heel-europa-klonk-het-hoe-ook-ons-landde-pandemieonderschatte $\sim \mathrm{b} 9 \mathrm{~d} 23 \mathrm{efc} /$ ?utm_campaign=shared_earned\&utm_medium=social\&utm_source=copylink 


\section{SUPPLEMENTARY MATERIAL}

\section{A. Survey Material}

\section{a1. Text used to publicize the study on social media}

"We are running a short 5 min survey to get an idea of people's moral opinions and risk perception concerning the Corona Covid-19 virus. We are looking to get as many people as possible to participate. Would be nice if you could spare us 5 min of your time. You're helping to advance science! Here's the link: xxx. Feel free to share. Thanks!"

\section{a2. Informed consent}

“In this survey we try to get an idea of people's moral opinions and risk perception concerning the Corona Virus.

The survey takes no longer than 5 minutes and is completely anonymous.

Participation in this survey is voluntary. You may choose not to participate. You can stop at any time without having to justify your choice.

The survey is part of a scientific project run by researchers from the University of Paris - Sorbonne under supervision of Dr. Wim De Neys (www.wdeneys.org).

Your individual privacy will be maintained in all published and written data resulting from the project.

By ticking the box below, you certify that you have read this form, and agree to participate in accordance with the above conditions.

I have read this form and agree to participate.

Click on the "->" button below to start."

\section{a3. Survey text}

"In response to the Corona/Covid-19 virus pandemic, many governments across the world enforced social distancing rules (e.g., keeping minimal distance, bans on gathering, stay-at-home measures) to slow the spread of the virus.

Please answer the following questions

1. To what extent do you feel that violating social distancing rules is morally condemnable (i.e., how "wrong" is such behavior)?

1 Totally fine to violate social distancing rules

2 Somewhat unacceptable to violate social distancing rules

3 Rather unacceptable to violate social distancing rules

4 Very unacceptable to violate social distancing rules 
5 Totally unacceptable to violate social distancing rules

2. How likely do you think it is that you will get Corona if you don't respect social distancing rules?

1 Extremely unlikely

2 Quite unlikely

3 Slightly unlikely

4 Neither likely nor unlikely

5 Slightly likely

6 Quite likely

7 Extremely likely

3. How likely do you think it is that you will infect somebody else if you don't respect social distancing rules?

1 Extremely unlikely

2 Quite unlikely

3 Slightly unlikely

4 Neither likely nor unlikely

5 Slightly likely

6 Quite likely

7 Extremely likely

\section{To what extent do you respect social distancing yourself?}

1 I never respect social distancing rules

2 I rarely respect social distancing rules

3 I mostly respect social distancing rules

4 I almost always respect social distancing rules

$5 \mathrm{I}$ always respect social distancing rules

For the next questions we ask you to go back in time to the day before your government enforced social distancing rules (i.e., the day before they became legally enforced). It was not illegal to refrain from respecting social distancing rules at that point. They were still just recommendations.

Try to remember how you felt and perceived things before social distancing was enforced and answer the following questions:

5. To what extent did you feel that violating social distancing recommendations was morally condemnable (i.e., how "wrong" did you feel that such behavior was) before they were enforced?

1 Totally fine to violate social distancing recommendations

2 Somewhat unacceptable to violate social distancing recommendations

3 Rather unacceptable to violate social distancing recommendations

4 Very unacceptable to violate social distancing recommendations

5 Totally unacceptable to violate social distancing recommendations

6. How likely did you think it was that you would get Corona if you did not follow social distancing recommendations before they were enforced?

1 Extremely unlikely

2 Quite unlikely

3 Slightly unlikely

4 Neither likely nor unlikely 
5 Slightly likely

6 Quite likely

7 Extremely likely

7. How likely did you think it was that you would infect somebody else if you didn't respect social distancing recommendations before they were enforced?

1 Extremely unlikely

2 Quite unlikely

3 Slightly unlikely

4 Neither likely nor unlikely

5 Slightly likely

6 Quite likely

7 Extremely likely

8. To what extent did you respect social distancing recommendations before they were enforced?

1 I never respected social distancing recommendations

2 I rarely respected social distancing recommendations

3 I mostly respected social distancing recommendations

4 I almost always respected social distancing recommendations

5 I always respected social distancing recommendations

In which country do you currently live?

Did the country or region where you currently live already enforce social distancing rules?

Yes

No

What is your age?

$<18,18-24,25-34,35-44,45-54,55-64,65-75,>75$

What is your gender?

Male

Female

What is the highest level of education you obtained?

Less than high school degree

High school degree

Bachelor degree

Master degree

Post master degree (MD, PhD, MBA, ...) 


\section{B. Supplementary Tables and Figure}

\section{b1. Demographics data}

Table S1. Descriptive Statistics

\begin{tabular}{|c|c|c|c|c|c|}
\hline \multirow[b]{2}{*}{ Valid } & \multicolumn{5}{|c|}{ Country Region enforced Age Gender Education } \\
\hline & 1417 & 1650 & 1651 & 1647 & 1636 \\
\hline Missing & 240 & 7 & 6 & 10 & 21 \\
\hline Mean & & 0.97 & 4.11 & 0.32 & 3.38 \\
\hline Median & & 1.00 & 4.00 & 0.00 & 3.00 \\
\hline Std. Deviation & & 0.16 & 1.53 & 0.47 & 1.00 \\
\hline Minimum & & 0.00 & 1.00 & 0.00 & 1.00 \\
\hline Maximum & & 1.00 & 8.00 & 1.00 & 5.00 \\
\hline
\end{tabular}

Table S2. Frequencies for Country

\begin{tabular}{lrrrr}
\hline & Country & Frequency & Percent Valid Percent Cumulative Percent \\
\hline Algeria & 5 & 0.30 & 0.35 & 0.35 \\
Argentina & 27 & 1.63 & 1.91 & 2.26 \\
Australia & 1 & 0.06 & 0.07 & 2.33 \\
Belgium & 280 & 16.90 & 19.76 & 22.09 \\
Bolivia & 2 & 0.12 & 0.14 & 22.23 \\
Bulgaria & 1 & 0.06 & 0.07 & 22.30 \\
Canada & 37 & 2.23 & 2.61 & 24.91 \\
Chile & 87 & 5.25 & 6.14 & 31.05 \\
China & 11 & 0.66 & 0.78 & 31.83 \\
Colombia & 3 & 0.18 & 0.21 & 32.04 \\
Costa Rica & 1 & 0.06 & 0.07 & 32.11 \\
Denmark & 3 & 0.18 & 0.21 & 32.32 \\
Finland & 3 & 0.18 & 0.21 & 32.53 \\
France & 403 & 24.32 & 28.44 & 60.97 \\
Georgia & 1 & 0.06 & 0.07 & 61.04 \\
Germany & 59 & 3.56 & 4.16 & 65.21 \\
Greece & 94 & 5.67 & 6.63 & 71.84 \\
Hong Kong (S.A.R.) & 1 & 0.06 & 0.07 & 71.91 \\
Hungary & 4 & 0.24 & 0.28 & 72.19 \\
India & 1 & 0.06 & 0.07 & 72.27 \\
Ireland & 2 & 0.12 & 0.14 & 72.41 \\
Italy & 134 & 8.09 & 9.46 & 81.86 \\
Kazakhstan & 1 & 0.06 & 0.07 & 81.93 \\
Madagascar & 3 & 0.18 & 0.21 & 82.15 \\
Mexico & 28 & 1.69 & 1.98 & 84.12 \\
Morocco & 3 & 0.18 & 0.21 & 84.33 \\
Netherlands & 28 & 1.69 & 1.98 & 86.31 \\
Nigeria & 1 & 0.06 & 0.07 & 86.38 \\
Paraguay & 2 & 0.12 & 0.14 & 86.52
\end{tabular}


Table S2. Frequencies for Country

\begin{tabular}{|c|c|c|c|c|}
\hline \multirow[t]{2}{*}{ Country } & \multicolumn{4}{|c|}{ Frequency Percent Valid Percent Cumulative Percent } \\
\hline & 5 & 0.30 & 0.35 & 86.87 \\
\hline Poland & 62 & 3.74 & 4.38 & 91.25 \\
\hline Portugal & 1 & 0.06 & 0.07 & 91.32 \\
\hline Romania & 3 & 0.18 & 0.21 & 91.53 \\
\hline Singapore & 1 & 0.06 & 0.07 & 91.60 \\
\hline Spain & 24 & 1.45 & 1.69 & 93.30 \\
\hline Sweden & 1 & 0.06 & 0.07 & 93.37 \\
\hline Switzerland & 6 & 0.36 & 0.42 & 93.79 \\
\hline Tunisia & 1 & 0.06 & 0.07 & 93.86 \\
\hline UK & 43 & 2.60 & 3.03 & 96.89 \\
\hline USA & 41 & 2.47 & 2.89 & 99.79 \\
\hline Uruguay & 1 & 0.06 & 0.07 & 99.86 \\
\hline Venezuela, Bolivarian Republic of... & 2 & 0.12 & 0.14 & 100.00 \\
\hline Missing & 240 & 14.48 & & \\
\hline Total & 1657 & 100.00 & & \\
\hline
\end{tabular}

Table S3. Frequencies for Region enforced

Region enforced Frequency Percent Valid Percent Cumulative Percent

\begin{tabular}{lrrrr}
\hline 0 Not enforced & 46 & 2.78 & 2.79 & 2.79 \\
1 Enforced & 1604 & 96.80 & 97.21 & 100.00 \\
Missing & 7 & 0.42 & & \\
Total & 1657 & 100.00 & & \\
\hline
\end{tabular}

Table S4. Frequencies for Age

\begin{tabular}{lrrrr}
\hline \multicolumn{1}{c}{ Age } & \multicolumn{5}{c}{ Frequency Percent Valid Percent Cumulative Percent } \\
\hline $1<18$ & 5 & 0.30 & 0.30 & 0.30 \\
$218-24$ & 228 & 13.76 & 13.81 & 14.11 \\
$325-34$ & 443 & 26.74 & 26.83 & 40.94 \\
$435-44$ & 372 & 22.45 & 22.53 & 63.48 \\
$545-54$ & 276 & 16.66 & 16.72 & 80.19 \\
$655-64$ & 196 & 11.83 & 11.87 & 92.07 \\
$765-75$ & 97 & 5.85 & 5.88 & 97.94 \\
$8>75$ & 34 & 2.05 & 2.06 & 100.00 \\
Missing & 6 & 0.36 & & \\
Total & 1657 & 100.00 & & \\
\hline
\end{tabular}

Table S5. Frequencies for Gender

\begin{tabular}{|c|c|c|c|c|}
\hline \multicolumn{5}{|c|}{ Gender Frequency Percent Valid Percent Cumulative Percent } \\
\hline 0 Female & 1115 & 67.29 & 67.70 & 67.70 \\
\hline 1 Male & 532 & 32.11 & 32.30 & 100.00 \\
\hline Missing & 10 & 0.60 & & \\
\hline Total & 1657 & 100.00 & & \\
\hline
\end{tabular}


Table S6. Frequencies for Education

\begin{tabular}{lrrrr}
\hline \multicolumn{1}{c}{ Education } & Frequency & Percent Valid & Percent Cumulative Percent \\
\hline 1 Less than high school degree & 45 & 2.72 & 2.75 & 2.75 \\
2 High school degree & 283 & 17.08 & 17.30 & 20.05 \\
3 Bachelor degree & 513 & 30.96 & 31.36 & 51.41 \\
4 Master degree & 592 & 35.73 & 36.19 & 87.59 \\
5 Post master degree (MD, PhD, MBA, ...) & 203 & 12.25 & 12.41 & 100.00 \\
Missing & 21 & 1.27 & & \\
Total & 1657 & 100.00 & & \\
\hline
\end{tabular}




\section{b2. Descriptive Ratings}

Table S7. Summary descriptive rating statistics

\begin{tabular}{lrrrrrrrr}
\hline & $\begin{array}{c}\text { Moral } \\
\text { condemnation }\end{array}$ & \multicolumn{1}{c}{$\begin{array}{c}\text { Likely } \\
\text { self }\end{array}$} & $\begin{array}{c}\text { Likely } \\
\text { other }\end{array}$ & Behavior & $\begin{array}{c}\text { Moral } \\
\text { condemnation } \\
\text { before }\end{array}$ & $\begin{array}{c}\text { Likely self } \\
\text { before }\end{array}$ & $\begin{array}{c}\text { Likely other } \\
\text { before }\end{array}$ & $\begin{array}{c}\text { Behavior } \\
\text { before }\end{array}$ \\
\hline Valid & 1652 & 1649 & 1642 & 1652 & 1652 & 1650 & 1639 & 1648 \\
Missing & 5 & 8 & 15 & 5 & 5 & 7 & 18 & 9 \\
Mean & 4.08 & 5.33 & 5.53 & 4.56 & 3.21 & 4.74 & 4.77 & 3.58 \\
Std. & 1.03 & 1.20 & 1.22 & 0.59 & 1.11 & 1.41 & 1.48 & 1.03 \\
Deviation & 1.00 & 1.00 & 1.00 & 2.00 & 1.00 & 1.00 & 1.00 & 1.00 \\
Minimum & 5.00 & 7.00 & 7.00 & 5.00 & 5.00 & 7.00 & 7.00 & 5.00 \\
Maximum & & & & & & & & \\
\hline
\end{tabular}




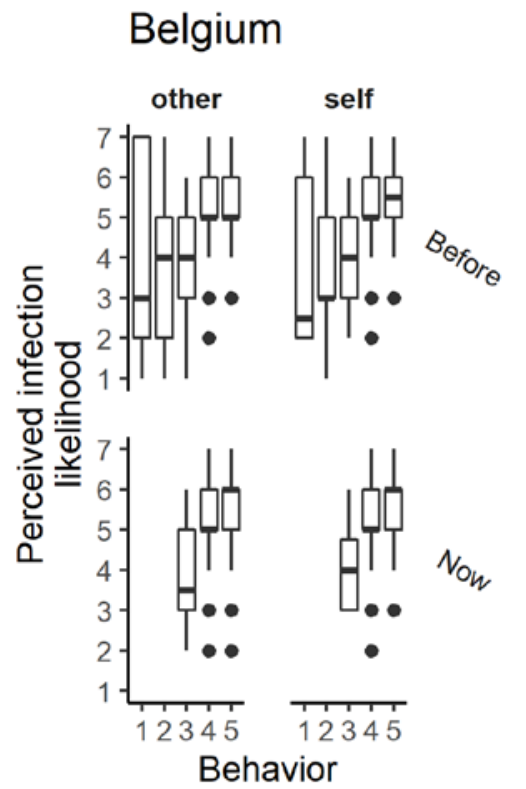

Belgium

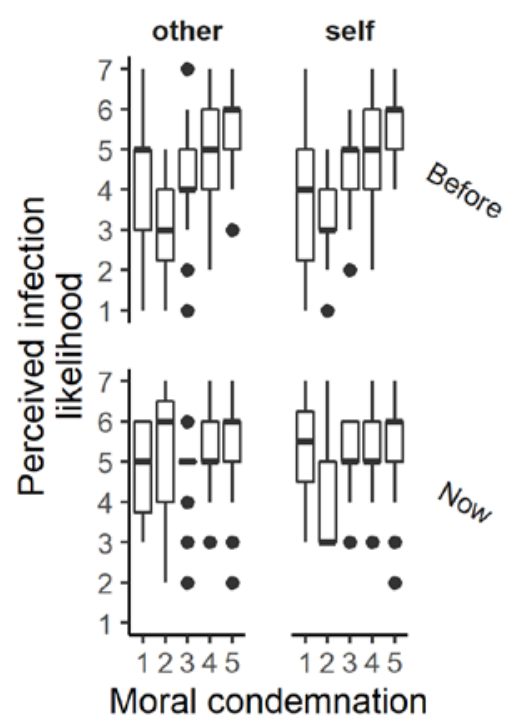

France
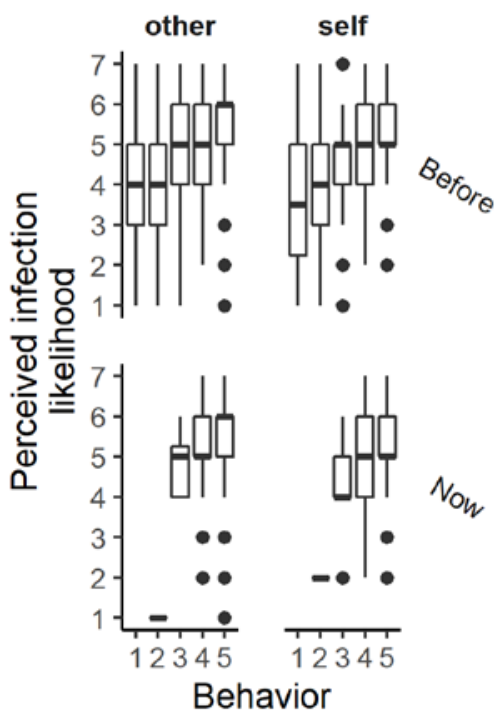

France

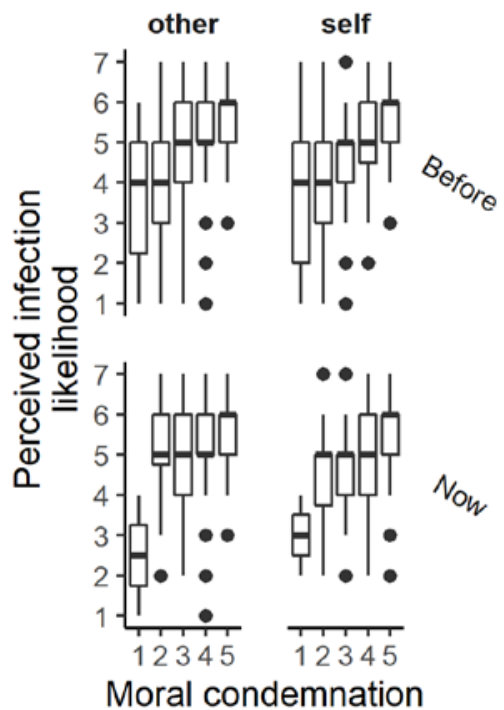

Italy
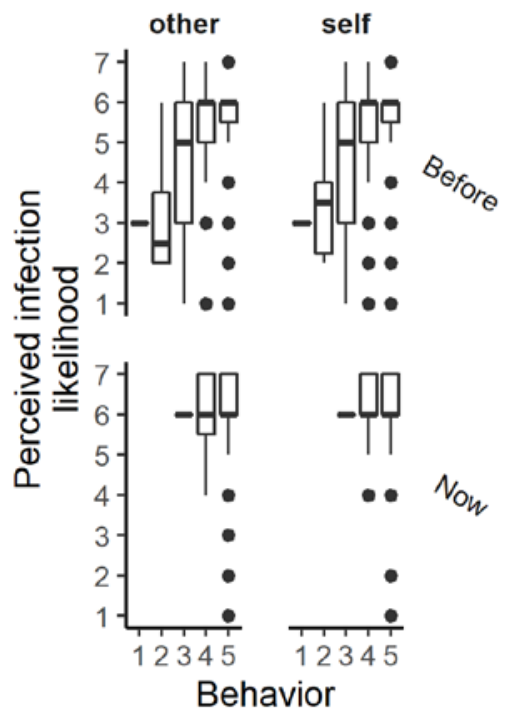

Italy

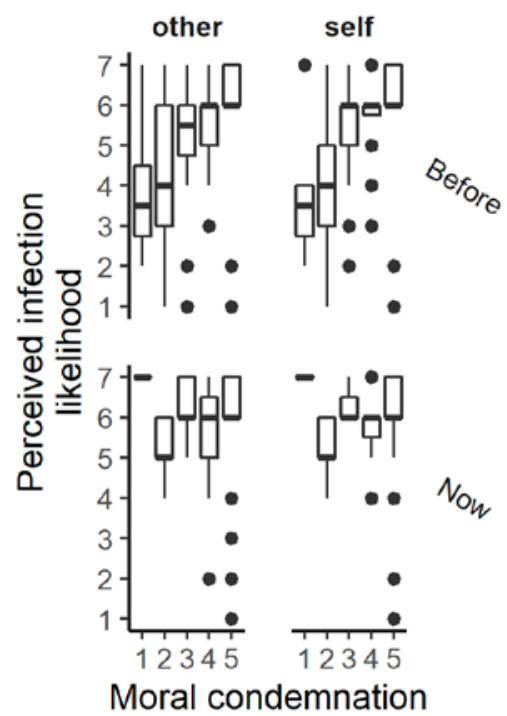

Figure S1. Boxplots illustrating the link between the perceived likelihood of Covid-19 infection (for others and self) and the extent to which participants report to respect social distancing ("Behavior") and condemn violations at Country level. The thick line represents the median. Boxes denote the interquartile range 


\section{b4. Country level correlation matrices}

Table S8. Correlation matrix France $(n=403)$

\begin{tabular}{|c|c|c|c|c|c|c|c|c|c|c|c|}
\hline & $\begin{array}{c}\text { Moral } \\
\text { condemnation }\end{array}$ & Likely self & $\begin{array}{l}\text { Likely } \\
\text { other }\end{array}$ & Behavior & $\begin{array}{c}\text { Moral condemnation } \\
\text { before }\end{array}$ & $\begin{array}{c}\text { Likely self } \\
\text { before }\end{array}$ & $\begin{array}{l}\text { Likely other } \\
\text { before }\end{array}$ & $\begin{array}{c}\text { Behavior } \\
\text { before }\end{array}$ & Age & Gender & Education \\
\hline Moral condemnation & - & & & & & & & & & & \\
\hline Likely self & $0.290 * * *$ & - & & & & & & & & & \\
\hline Likely other & $0.279 * * *$ & $0.693 * * *$ & - & & & & & & & & \\
\hline Behavior & $0.346 * * *$ & $0.190 * * *$ & $0.182 * * *$ & - & & & & & & & \\
\hline $\begin{array}{l}\text { Moral condemnation } \\
\text { before }\end{array}$ & $0.429 * * *$ & $0.205 * * *$ & $0.170 * * *$ & $0.233 * * *$ & - & & & & & & \\
\hline Likely self before & $0.258 * * *$ & $0.495 * * *$ & $0.429 * * *$ & $0.220 * * *$ & $0.436 * * *$ & - & & & & & \\
\hline Likely other before & $0.216 * * *$ & $0.397 * * *$ & $0.538 * * *$ & $0.154 * *$ & $0.394 * * *$ & $0.817 * * *$ & - & & & & \\
\hline Behavior before & $0.342 * * *$ & $0.150 * *$ & $0.137 * *$ & $0.391 * * *$ & $0.629 * * *$ & $0.392 * * *$ & $0.365 * * *$ & - & & & \\
\hline Age & $0.116 *$ & 0.059 & 0.054 & $0.133 * *$ & $0.152 * *$ & 0.078 & 0.044 & $0.174 * * *$ & - & & \\
\hline Gender & $-0.139 * *$ & $0.163^{-* *}$ & $-0.159 * *$ & $0.033^{-}$ & -0.063 & $-0.152 * *$ & $-0.145 * *$ & -0.040 & $0.126 *$ & - & \\
\hline Education & 0.061 & 0.049 & -0.034 & $0.114 *$ & 0.097 & 0.069 & 0.070 & $0.138 * *$ & 0.098 & 0.033 & - \\
\hline
\end{tabular}

Table S9. Correlation matrix Belgium $(n=280)$

\begin{tabular}{|c|c|c|c|c|c|c|c|c|c|c|c|}
\hline & $\begin{array}{c}\text { Moral } \\
\text { condemnation }\end{array}$ & Likely self & $\begin{array}{l}\text { Likely } \\
\text { other }\end{array}$ & Behavior & $\begin{array}{c}\text { Moral condemnation } \\
\text { before }\end{array}$ & $\begin{array}{l}\text { Likely self } \\
\text { before }\end{array}$ & $\begin{array}{l}\text { Likely other } \\
\text { before }\end{array}$ & $\begin{array}{c}\text { Behavior } \\
\text { before }\end{array}$ & Age & Gender & Education \\
\hline Moral condemnation & - & & & & & & & & & & \\
\hline Likely self & $0.286 * * *$ & - & & & & & & & & & \\
\hline Likely other & $0.299 * * *$ & $0.741 * * *$ & - & & & & & & & & \\
\hline Behavior & $0.465 * * *$ & $0.245 * * *$ & $0.281 * * *$ & - & & & & & & & \\
\hline $\begin{array}{l}\text { Moral condemnation } \\
\text { before }\end{array}$ & $0.497 * * *$ & $0.151 *$ & $0.137 *$ & $0.375 * * *$ & - & & & & & & \\
\hline Likely self before & $0.300 * * *$ & $0.407^{* * *}$ & $0.384 * * *$ & $0.262 * * *$ & $0.589 * * *$ & - & & & & & \\
\hline Likely other before & $0.266 * * *$ & $0.367^{* * *}$ & $0.433 * * *$ & $0.264 * * *$ & $0.530 * * *$ & $0.859 * * *$ & - & & & & \\
\hline Behavior before & $0.364 * * *$ & $0.146 *$ & $0.149 *$ & $0.434 * * *$ & $0.630 * * *$ & $0.511 * * *$ & $0.465 * * *$ & - & & & \\
\hline Age & $0.303 * * *$ & 0.087 & 0.002 & $0.184 * *$ & $0.255^{* * *}$ & $0.126 *$ & $0.131 *$ & $0.219 * * *$ & - & & \\
\hline Gender & -0.087 & $0.133^{-*}$ & $-0.142 *$ & 0.092 & -0.032 & $-0.122 *$ & -0.076 & $-0.137^{*}$ & $0.205^{* * *}$ & - & \\
\hline Education & $-0.155 *$ & 0.095 & $-0.127 *$ & $\begin{array}{r}- \\
0.055^{-}\end{array}$ & -0.098 & -0.061 & -0.079 & -0.047 & $-0.153 *$ & $0.121 *$ & - \\
\hline
\end{tabular}

${ }^{*} \mathrm{p}<.05,{ }^{* *} \mathrm{p}<.01,{ }^{* * *} \mathrm{p}<.001$ 
Table S10. Correlation matrix Italy $(n=134)$

Moral condemnation Likely self Likely other Behavior Moral condemnation before Likely self before Likely other before Behavior before

Gender Education

Moral condemnation

Likely self

Likely other

Behavior

$0.188 *$

Moral conder

$0.178 *$ $-$

befor

Likely self before

$0.295 * * * \quad 0.008 \quad-0.025$

$0.425 * * * \quad 0.250 * * \quad 0.254 * * \quad 0.219 *$

ikely other before

0.123

$0.460 * * * \quad 0.445 * * * \quad 0.198 *$

havior befor

0.134

$0.418 * * * \quad 0.491 * * * \quad 0.131$

$\begin{array}{llll}0.234 * * & -0.020 & -0.006 & 0.274 * *\end{array}$

Age

$0.209 *$

$\begin{array}{lll}0.094 & 0.093 & 0.120\end{array}$

$\begin{array}{llll}-0.057 & -0.162 & -0.091 & 0.058\end{array}$

Education

$-0.071$

$-0.056-0.095$

0.067

$0.533 * *$

$0.493 * * *$

$0.555^{* * *}$

$0.306^{* * *}$

$0.858^{* * *}$

$0.361 * * *$

0.156
-0.036
-0.092

0.104

0.072

${ }^{*} p<.05,{ }^{* *} p<.01,{ }^{* * *} p<.001$

0.010

$-0.109$

$-0.000 \quad 0.080$

$-0.020-0.365 * * *-0.119$ 